\title{
NOTES
}

\section{RESPONDING KISSES: NEW EVIDENCE ABOUT THE ORIGINS OF "VIGIL STRANGE I KEPT ON THE FIELD ONE NIGHT"}

"Vigil Strange I Kept on the Field One Night," one of Walt Whitman's DrumTaps poems, dramatizes a soldier's death in battle and the subsequent vigil kept over his body by a comrade in arms. ${ }^{1}$ Charles Glicksberg has suggested that the poem originated in the circumstances surrounding the death of Whitman's soldier friend named Bill, as relayed to the poet by a mutual friend named Arthur. ${ }^{2}$ Given the poem's literary and biographical significance, it may prove interesting to see how the circumstances of Bill's actual death coincide with Whitman's imagined account and by so doing inform our reading of Whitman's poem.

Glicksberg's conjecture about the poem's genesis is based on an entry in Whitman's notebook, which reads:

William Giggee, Sept. 18 $8^{\text {th }}$ '62. I heard of poor Bill's death-he was shot on Pope's retreat-Arthur took him in his arms, and he died in about an hour and a half-Arthur buried him himself he dug his grave ${ }^{3}$

In addition to Whitman's rough note, Bill's and Arthur's military service records shed some additional light on this episode. Both soldiers, curiously enough, shared the surname Giggie (the spelling most commonly used in their service records), and served together as privates in the First New York Infantry. ${ }^{4}$ Bill was twenty-one when he enlisted in April 1861, just days after the attack on Fort Sumter, and Arthur was twenty-two when he enlisted the following month. Their regiment engaged in battles at Big Bethel, Virginia (June 1861), and those of the Peninsula Campaign (Spring 1862) before participating in Union General John Pope's Virginia Campaign in the summer of 1862. In an engagement at Groveton, on August 29, 1862, during the second battle of Manassas, Bill Giggie was killed.

Arthur relayed the news of Bill's death in a letter to Bill's mother, Elizabeth, who later provided it to the U.S. Pension Office in support of her claim for a survivor's benefit. ${ }^{5}$ In his letter to Elizabeth Giggie, Arthur writes:

I have taken the liberty about 2 weeks ago to address you \& make you acquainted with the sad news that on the $29^{\text {th }}$ of August in the battle of Manassas Plains my friend William Giggie was killed by a Minie ball which entered near the heart. I stood next to him and with the help of some other Comrade brought him to the hospital but he expired before reaching it in my arms without much struggle. I was lucky enough to find a resting place for his remains beyond the hospital before the enemies drove us from our position. 
Comparing the actual circumstances of Bill Giggie's death to Whitman's poetic version, we see that the two accounts are in harmony on the essential element of two soldiers fighting side by side, one of whom is killed and buried by the survivor in the war zone. In addition, the date of Bill's death in late August 1862 supports the chronological placement of "Vigil Strange" in the Drum-Taps cluster (1881 edition) shortly before the battle of Fredericksburg in December 1862 (which is represented by "A Sight in Camp in the Daybreak Gray and Dim"). That the poem was based on the death of an actual person whom Whitman knew reinforces its elegiac qualities, particularly as the poem is presented through the eyes of the principal survivor and mourner.

The soldiers' relationship to one another is ambiguous in both Arthur's account and Whitman's poem. William and Arthur share the unusual surname Giggie, but they do not appear to be blood relations. Otherwise, we might expect Arthur in his letter to address Mrs. Giggie with less formality, and refer to Bill as kin, rather than as "friend." From Mrs. Giggie's pension application, we can glean some additional information about Bill. He was born around 1842 in New York, the oldest of Ira and Elizabeth Giggie's two sons. Bill's father abandoned his family when Bill was ten. Thereafter, his mother supported herself and her sons by operating a Manhattan boarding house that catered principally to the city's stagecoach drivers. It is possible that Whitman met Bill through one of the Giggie's boarders, or that Bill himself was also a driver. Whitman loved to ride the city's street coaches and befriended many of the colorful drivers, whom he regarded as "a strange, natural, quick-eyed and wondrous race." Arthur, however, remains a mystery; he did not claim a pension, which would have been a useful source of biographical information, and he is not listed in census or city directories for New York before or after the war.

Given that Arthur and Bill shared an unusual surname but apparently were not related, and that there is no evidence that Arthur carried this surname before or after the war, one wonders if Arthur assumed his friend Bill's family name around the time of their enlistment, and if so, for what purpose? One possibility is that they were lovers who presented themselves as a family unit. Doing so might have allowed them to assert such familial privileges as shared personal quarters and duty assignments. The interpretation of their relationship (blood kin or conjugal couple) might have been left purposefully ambiguous, thus not explicitly challenging the comfort levels (to use a popular modern idiom) of those indisposed to such friendships.

Recent historical research suggests that such same-sex couples were not as unusual in this era as we previously may have supposed. David Greenberg, for example, notes the emergence of "male homosexual networks" in New York City in the middle of the nineteenth century, along with "recognized cruising grounds and, from the 1830s on, all-male social clubs." Jonathan Ned Katz, in his aptly named Love Stories: Sex Between Men Before Homosexuality, has found in official military records as well as soldier's personal correspondence many suggestions of same-sex intimacy in the ranks. ${ }^{8}$ We generally assume that Whitman himself was homosexual, and that he was coupled before the War with Fred Vaughan and, around the time he was preparing Drum-Taps for publication, with Pete Doyle, the Washington horse-car conductor. Robert 
Scholnick suggests that Whitman's homosexuality was acknowledged and accepted by his Bohemian contemporaries at Pfaff's. ${ }^{9}$

In "Vigil Strange," Whitman appears to adopt Bill and Arthur's strategy of ambiguity. Whitman introduces an age difference between his poetic soldiers that did not meaningfully exist between Bill and Arthur, with the use of the endearment, "son of responding kisses." This invites a literal reading of a father and son serving in the same regiment. ${ }^{10}$ Yet this endearment, coupled with other Platonic imagery in the poem, would also support a reader's assumption that the soldiers were a warrior couple fashioned from a classical Greek model. ${ }^{11}$ Whitman's understanding of Greek eros came from his reading of Plato in the six-volume Bohn edition, which contained both the "Phaedrus" and "Banquet" (also known as the "Symposium") essays. ${ }^{12}$ On the former, Whitman noted, " $[\mathrm{B}] \mathrm{y}$ love he evidently means the passion inspired in one man, by another man, more particularly a : beautiful youth." ${ }^{13}$ (It might also have pleased Whitman to fashion the surviving soldier more in his own image as a middle-aged man whose principal passion was for younger men.)

Plato's "Banquet" essay (in the speech of Phaedrus) extols the virtues of lovers serving together as warriors, since a lover would never act in a manner other than valorous whilst in the presence of his beloved:

If then there could be any contrivance to form a city or an army of persons loving and loved, it is not possible for them to regulate their own country better than by abstaining from every thing base, and having a desire to be honoured by one another (for what is noble); and fighting side by side, such persons, although few in number, would conquer, so to say, the whole world. For a lover would less endure to be seen by his beloved, when deserting his post, or throwing away his arms, than by all the others; and in preference to this, either to leave behind his beloved (when he has fallen,) or not to assist him when in danger, he would rather die many deaths. There is not a man so much of a coward as that Love would not divinely inspire him to deeds of valour, and make him equal to the very best by birth. (Plato, v. 3, p. 487-489)

A similar sentiment is expressed in Plutarch's Lives (a work cited by Whitman), in which the legend of the Sacred Band of Thebes is recounted in the Life of Pelopidas (NUPM 5:1875). Whitman also slightly changes the narrative of Bill's death and burial to create a more reassuringly loyal story line. In the poem, the surviving soldier continues to fulfill his duty "in the even-contested battle" even as his loving comrade falls, wounded yet still alive; rather than abandon his station to tend immediately to his wounded comrade as Arthur did for Bill, the poetic soldier continues to fight while the battle rages and only returns to his comrade when the fighting has lulled. This variation in Bill and Arthur's story reinforces the association with the Theban Band. Quoting from the Langhorne edition, "This small body was ... the very flower of the Theban army, and was dignified by the names of the sacred battalion and the band of lovers . . . being equally famed for their fidelity to the Theban state, and affection for each other."14 Whitman's advocacy for same-sex couples in "Vigil Strange" is in keeping with similar sentiments expressed in other poems of this period, including "I Dream'd in a Dream" and "I Hear It Was 
Charged Against Me," and later in "The Base of all Metaphysics," which Whitman believed lay in "The dear love of man for his comrade, the attraction of friend to friend." 15

"Vigil Strange" carries the Platonic imagery through the closing stanza, in which the surviving soldier is consoled for his loss by gazing at a star-filled sky:

Vigil of silence, love and death, vigil for you my son and my soldier,

As onward silently stars aloft, eastward new ones upward stole,

Vigil final for you brave boy, (I could not save you, swift was your death,

I faithfully loved you and cared for you living, I think we shall surely meet again,)

In Platonic mysticism, a soul sprouts wings and returns to the heavens if, while in human form, it has loved a perfect companion and otherwise has accorded itself justly. What had begun as a lament- "son of responding kisses, (never again on earth responding,)" - now becomes an affirmation of the soul's immortality and the hope of reunification of lover and beloved after death. This ending contains a further ambiguity regarding the soldier's relationship, as a traditional reading of Plato's "Phaedrus" would argue that the highest form such friendships can take is a sexually chaste one. Regardless, Whitman has left for us a heartfelt testimonial to the love story of Bill and Arthur Giggie.

The Washington Friends of Walt Whitman

Martin G. Murray

\section{NOTES}

1 Walt Whitman, Leaves of Grass: Comprehensive Reader's Edition, ed. Harold W. Blodgett and Sculley Bradley (New York: New York University Press, 1965), 303305.

2 Charles Irving Glicksberg, Walt Whitman and the Civil War: A Collection of Original Articles and Manuscripts (New York: Arno Press, 1963), 142.

3 Walt Whitman, Notebooks and Unpublished Prose Manuscripts, ed. Edward F. Grier (New York: New York University Press, 1984), 2:493.

4 See the National Archives and Records Administration (NARA), Record Groups (RG) 94 and 15. The service records also include the following variant spellings of Giggie: Giggee and Gigger. The 1860 population census for New York City lists Bill's family under the name Geggy.

5 The pension file contains a hand-written copy of Arthur's letter. According to Elizabeth Giggie, the original letter from Arthur had been sent to the Office of the Second Auditor of the Treasury in an application for a bounty. Mrs. Giggie had this copy notarized as a true copy of the original's content. In full the letter reads: 
Mrs. E. Giggie New York

Camp near Fort Ward Va., Sept. 14/62

I have taken the liberty about 2 weeks ago to address you $\&$ make you acquainted with the sad news that on the $29^{\text {th }}$ of August in the battle of Manassas Plains my friend William Giggie was killed by a Minie ball which entered near the heart. I stood next to him and with the help of some other Comrade brought him to the hospital but he expired before reaching it in my arms without much struggle. I was lucky enough to find a resting place for his remains beyond the hospital before the enemies drove us from our position. Their is due to him the wages since the first of July \& this with his bounty of $\$ 100.00$ you as the nearest kin to him can claim wich way I do not know but you soon will find out in the City. Feeling with you the heavy loss you sustain I can tell you that he has left no enemies under his comrades as all has loved him like a brother. We are marching so much around that I have found no time yet to send you a ring which I took from his finger but so soon I come across the Express office will send it to you as I am afraid you will not receive it in a letter as I think you have not received the letter I wrote to you on the first of September. My direction is Arthur Giggie Co. E, 1 N.Y. Armee of the Potomak, Kearney Division, Camp near Fort Ward, Va. I will be happy to hear from you and signed

\section{Respectfully}

\section{Arthur Giggie}

Enclosed I send you a letter I took from his pocket.

6 Walt Whitman, Prose Works 1892, ed. Floyd Stovall (New York: New York University Press, 1963), 1:18.

7 David F. Greenberg, The Construction of Homosexuality (Chicago: The University of Chicago Press, 1988), 355.

8 Jonathan Ned Katz, Love Stories: Sex Between Men Before Homosexuality (Chicago: The University of Chicago Press, 2001), 134-136.

9 Robert J. Scholnick, “'An Unusually Active Market for Calamus': Whitman, Vanity Fair, and the Fate of Humor in a Time of War, 1860-1863," Walt Whitman Quarterly Review 19 (Winter/Spring 2002), 148-181.

10 See, for example, M. Wynn Thomas, The Lunar Light of Whitman's Poetry, (Cambridge, MA: Harvard University Press, 1987), 208. Thomas provides this synopsis of the poem's action: "[T] he father, having sped onward in the battle, returns to find the body of his son, to keep vigil, and to perform the last rites of love." Indeed, Bill's father, Ira Giggie, did serve in the military during the War, although not in the same regiment as his son and, as earlier indicated, father and son apparently were estranged.

11 Excellent treatments of Whitman's indebtedness to Platonic imagery and philosophy may be found in: Robert K. Martin, The Homosexual Tradition in American Poetry: An Expanded Edition (Iowa City: University of Iowa Press, 1998); Byrne R.S. Fone, Masculine Landscapes: Walt Whitman and the Homoerotic Text (Carbondale and Edwardsville: Southern Illinois University Press, 1992); and David Kuebrich, Minor Prophecy: Walt Whitman's New American Religion (Bloomington and Indianapolis: Indiana University Press, 1989). 
12 Plato, The works of Plato: a new and literal version, chiefly from the text of Stallbaum, vol. 1, ed. Henry Cary; vol. 2, ed. Henry Davis; vols. 3-6, ed. George Burges (London: Bohn, 1849-1854). The "Phaedrus" essay is in vol.1 (1854), and the "Banquet" essay is in vol. 3 (1850).

\section{Whitman, NUPM, 5:1882.}

14 Plutarch, Plutarch's Lives, Translated from the Original Greek: with Notes, Critical and Historical: and A Life of Plutarch, ed. John Langhorne, D.D., and William Langhorne, A.M. (Cincinnati: Applegate \& Co., 1856), 205-206. According to Floyd Stovall, Whitman read this particular edition of Plutarch's Lives (see Stovall, The Foreground of Leaves of Grass [Charlottesville: University Press of Virginia, 1974], 175).

15 Whitman, Leaves of Grass, 121.

\section{THREE UNPUBLISHED WHITMAN LETTERS TO HARRY STAFFORD AND A SPECIMEN DAYS PROSE FRAGMENT}

Kendall Reed has recently added to his Whitman collection three previously unpublished letters from the poet to Harry Stafford. These letters add further documentation to the long, intense, sometimes stormy, often puzzling relationship between Whitman and Stafford, whom Whitman met in Camden in 1876 when Harry was just eighteen years old and running errands at the Camden New Republic, where Whitman often went to work on preparing the Centennial Edition of Leaves of Grass. Their close friendship lasted eight years, until Harry got married in 1884; after that, Whitman continued to write occasional brief letters to Harry and his wife Eva, and in his will he left Harry his silver watch. ${ }^{1}$ These three new letters-identified in Edwin Haviland Miller's edition of The Correspondence as "lost" and "formerly in the possession of Alfred F. Goldsmith" - bring to over forty the number of known Whitman letters to Harry. Harry's known letters to Whitman, now numbering more than thirty, have been published in various places. ${ }^{3}$

\section{Letter 1:}

Camden

Sunday

Sept: $10[1882]$

\section{Dear Harry}

Thanks for your good letter-I have had my hands full the last six or eight weeks getting my new book in shape, seeing to every thing, and watching the proofs day \& night ${ }^{4}$ - (I have had to read the proofs at night all through) - But now it is over \& I begin to feel free again-(And yet I must say I kind of enjoy it, \& should like to go through the same job two or three times a year) - I have had the mighty good luck to keep well this summer all through-my usual bad spell (I always expect one after I have felt pretty good awhile) has not come on-

[page break] 